\title{
String of pearls around the brainstem
}

\section{A case of neurosarcoidosis}

\section{Figure MRI findings of leptomeningeal neurosarcoidosis}
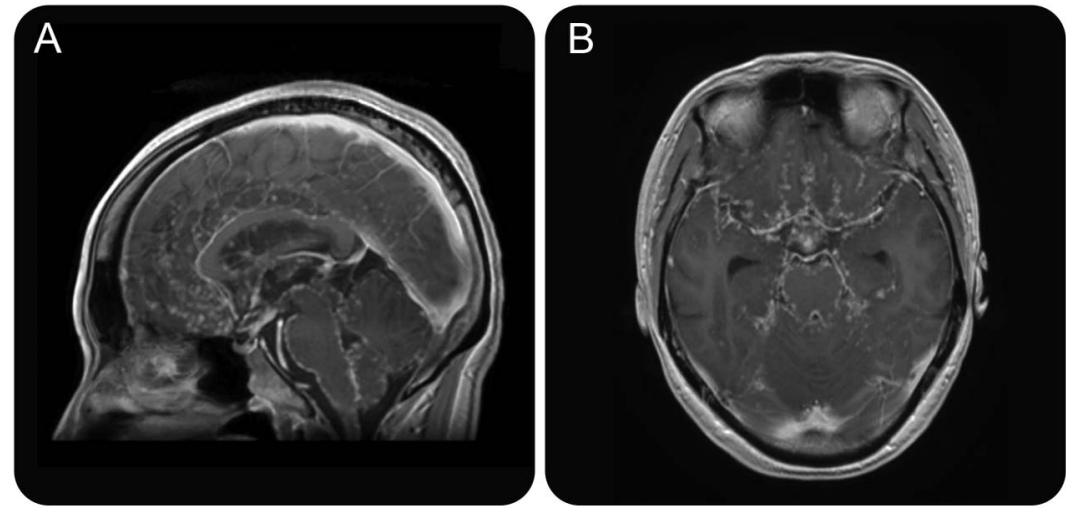

Sagittal (A) and axial (B) section of T1-weighted, gadolinium-enhanced brain MRI on admission.

A 35-year-old woman presented with 2 months of chronic headache. Her history was remarkable for bilateral uveitis. There was no nuchal rigidity or neurologic deficit. CSF revealed a lymphocytic pleocytosis, elevated protein, and hypoglycorrhachia $(23 \mathrm{mg} / \mathrm{dL})$. Culture for acid-fast bacilli was negative. Chest $\mathrm{x}$-ray revealed bilateral hilar lymphadenopathy. There was an increased CD4/CD8 ratio in a bronchoalveolar lavage sample. Angiotensin-converting enzyme was $14.5 \mathrm{IU} / \mathrm{L}$. Brain MRI disclosed nodular leptomeningeal enhancement mainly along the brainstem, with a "string of pearls" appearance (figure). Less than $20 \%$ of cases of neurosarcoidosis show moderate hypoglycorrhachia, ${ }^{1}$ and most of them had leptomeningeal involvement.

Hyoh Kim, MD, PhD, Jiro Oi, MD, PhD, Isamu Yamakawa, MD, PhD, Hiromichi Kawai, MD, PhD

From the Department of Neurology, Shiga University of Medical Science, Japan.

Author contributions: All authors involved with the patient's care. Hyoh Kim: conception and design of the study, interpretation of the data, drafting of manuscript for intellectual content. Jiro Oi: acquisition and analysis of the data, revision of manuscript for intellectual content. Isamu Yamakawa: acquisition and analysis of the data, revision of manuscript for intellectual content. Hiromichi Kawai: conception and design of the study, critical revision of manuscript for important intellectual content, final approval of the version published.

Study funding: No targeted funding reported.

Disclosure: The authors report no disclosures relevant to the manuscript. Go to Neurology.org for full disclosures.

Correspondence to Dr. Kawai: hirok@belle.shiga-med.ac.jp

1. Pawate S, Moses H, Sriram S. Presentations and outcomes of neurosarcoidosis: a study of 54 cases. QJM 2009;102:449-460. 


\section{Neurology}

\section{String of pearls around the brainstem: A case of neurosarcoidosis \\ Hyoh Kim, Jiro Oi, Isamu Yamakawa, et al. \\ Neurology 2016;87;2602 \\ DOI 10.1212/WNL.0000000000003438}

This information is current as of December 12, 2016

Updated Information \&
Services

References

Subspecialty Collections

Permissions \& Licensing

Reprints including high resolution figures, can be found at: http://n.neurology.org/content/87/24/2602.full

This article cites 1 articles, 0 of which you can access for free at: http://n.neurology.org/content/87/24/2602.full\#ref-list-1

This article, along with others on similar topics, appears in the following collection(s):

\section{Meningitis}

http://n.neurology.org/cgi/collection/meningitis

MRI

http://n.neurology.org/cgi/collection/mri

Information about reproducing this article in parts (figures,tables) or in its entirety can be found online at:

http://www.neurology.org/about/about_the_journal\#permissions

Information about ordering reprints can be found online:

http://n.neurology.org/subscribers/advertise

Neurology ${ }^{\circledR}$ is the official journal of the American Academy of Neurology. Published continuously since 1951, it is now a weekly with 48 issues per year. Copyright (O 2016 American Academy of Neurology. All rights reserved. Print ISSN: 0028-3878. Online ISSN: 1526-632X.

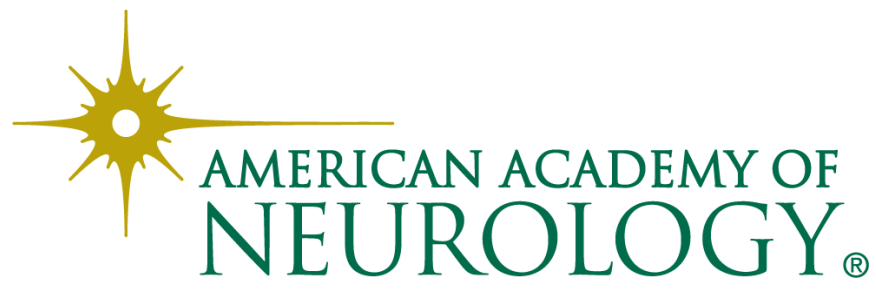

